\title{
Ernst Hirsch Ballin, Citizen's Rights and the Right to be a Citizen
}

\author{
Tamar de Waal
}

Ernst Hirsch Ballin, Citizen's Rights and the Right to be a Citizen (Brill | Nijhoff, 2014) ISBN 978-90-0422-318-9

Citizens' Rights and the Right to Be a Citizen discusses how modern twenty-first century European societies can bridge the gap between the universality of human rights - that apply to all without distinction - and the political and social setting in which people participate in a democratic society. The author, Ernst Hirsch Ballin, was Netherlands Minister of Justice from 1989 to 1994 and 2006 to 2010 and is now professor of Human Rights Law at the University of Amsterdam and Professor of Dutch and European Constitutional Law at Tilburg University. The book springs from the inaugural address he gave in 2011 in Amsterdam, which was (in part) intended as a 'personal statement' (p. ix) after Hirsch Ballin's longstanding involvement in political life came to an end. His political party (CDA, Christian-Democrats) formed a coalition government with the support of an antiimmigrant political movement (PVV, Party of Freedom). This statement resulted to be a thorough investigation of the intrinsic interconnections between democracy, the constitutional state, and international human rights.

In the book, Hirsch Ballin reflects on the constitutional significance of citizenship rights against the backdrop of the ongoing migration and urbanization in the beginning of the twenty-first century. This development triggers a myriad of political and constitutional questions, including issues of nationality, identity, EU-citizenship, statelessness, civic virtues, gender, and multiple citizenships. In less than 140 pages, the text discusses all these topics (and more) and cumulates in a defence for a human right to be a citizen.

In the main, the constructive argument that is put forward is that questions of citizenship should be predominately understood through the recognition of international human rights. In the terminology of the author, this is required as citizens' rights are the essential connecting link between human rights and life in a democratic society, as for human rights to be protected and effectuated a constitutional order is required with legislative powers and an independent judiciary (p. 121). International human rights law gives to all individuals the right to be a citizen and to take part in the democratic process of the state where a person is effectively at home. Therefore, the protection of citizens (still) relies on the ongoing relationship that individuals have with specific states. Yet, the legal recognition of being a citizen by a particular state simultaneously mirrors the commitment of this state to the universal human right to citizenship that should be granted irrespective of personal characteristics (e.g., sex, race, religion, beliefs, 
sexual orientation). States are thus necessary for justice, peace, and prosperity, but 'recognizing the right to be a citizen as a human right places citizenship at the centre of human rights' (p. 123).

With this argument, Hirsch Ballin radically links the significance of human right laws and universal cosmopolitan values to the legal frameworks that distribute the national citizenship rights of modern democracies. On that account, the ultimate implication of the book is that democratic states are under a legal obligation to recognize all permanent residents on their territories, who are due to their residency and participation de facto integrated members of their society, as citizens. Otherwise, so if persons who are effectively 'at home' in a certain nation would be excluded from citizenship, this would imperil the legal principles that define and legitimize the democratic state. This is a progressive idea (which, in a different form, is also proposed by Ruth Rubio Marin in her book Immigration as a Democratic Challenge). It indicates that the sovereignty of the democratic state is limited by its own principles related to those who belong to its demos, that is, the group of individuals that forms the citizenry. The boundaries of democratic selfgovernance are tied to the extent that the state upholds constitutional relationships with those that should acquire citizenship (p. 122). To substantiate this line of reasoning, Hirsch Ballin explicitly concurs with philosopher Seyla Benhabib who says that both a 'reconfiguration of sovereignty' and 'reconstructions of citizenship' (p. 84) are taking place, for which new legal frameworks have to be found based primarily on residency.

The main Achilles heel of the book is that while it presents an appealing and farreaching line of reasoning, the intricate specifics of the legal and normative implications are not discussed in-depth. Rather, the book considers an extensive list of themes that all indicate that citizenship rights are key to the protection of certain fundamental rights, particularly during times of migration. As a result, some sections remain somewhat open-ended. For example, in chapter 3, the issue of naturalization is discussed: the process through which a non-citizen in a country may acquire the national citizenship of that country. Prima facie, this seems an interesting case through the lens of the pivotal argument of the book that, as said, suggests that receiving states cannot, in addition to prolonged residency, install evaluative criteria as conditions of citizenship rights as international laws stipulate citizenship should be given to de facto members of society irrespective of their characteristics.

However, in this section, Hirsch Ballin notes that a 'sufficient command of the country's official language is a reasonable criterion for the acquisition of citizenship' (p. 85). Yet, how should we understand this in relation to his legal proposition that denying citizens rights to permanent residents 'amounts to exclusion of the process of realizing of human rights' (p. 121)? Is it constitutional to deny people their basic human and democratic rights on the basis of too low language levels? To be sure, perhaps there are good reasons for this policy proposal, even though it (seemingly) contradicts with the normative outlook of the rest of the book. But such reasons are not commented on exhaustively. Instead, the text is 
filled with a multitude of other related social and political issues that also indicate the constitutional significance of citizenship. This goes, at times, at the expense of the readability of the book.

Nonetheless, in summary, Hirsch Ballins' book provides a profound and original perspective on the future of national citizenship. Resuming his academic work after a lengthy political career, the author connects a wide variety of pressing contemporary political and constitutional issues with long-lasting academic debates. I would recommend it to political and legal scholars interested in the connections between democracy, the rule of law, and international human rights and to those interested in the governance of national citizenship in an increasingly interconnected and globalized world. 